\title{
Pengaruh Kemampuan Awal Matematika dan Motivasi Belajar Terhadap Hasil Belajar Matematika
}

\author{
Witri Lestari \\ Program Studi Pendidikan Matematika FTMIPA Unindra PGRI Jakarta \\ E-mail: witrilestari.unindra@gmail.com
}

Dikirim: Februari 2017; Diterima: Mei 2017; Dipublikasikan: Juni 2017

\begin{abstract}
Abstrak. Tujuan dari penelitian adalah untuk mengetahui: 1) pengaruh kemampuan awal matematika terhadap hasil belajar matematika; 2) pengaruh motivasi belajar terhadap hasil belajar matematika; 3) pengaruh interaksi kemampuan awal matematika dan motivasi belajar terhadap hasil belajar matematika. Penelitian ini menggunakan metode survey dengan mengambil responden sebanyak 99 responden. Penelitian ini dilaksanakan pada SMP Negeri 41, SMP Negeri 218 dan SMP Negeri 227 Jakarta. Pengujian hipotesis dilakukan dengan menggunakan SPSS 15.0 for windows pada taraf signifikansi 0,05. Penelitian ini menghasilkan tiga kesimpulan utama, yaitu; pertama, terdapat pengaruh kemampuan awal matematika terhadap hasil belajar matematika; kedua terdapat pengaruh motivasi belajar terhadap hasil belajar matematika; ketiga terdapat pengaruh interaksi kemampuan awal matematika dan motivasi belajar terhadap hasil belajar matematika peserta didik.
\end{abstract}

Kata Kunci: Kemampuan Awal Matematika, Motivasi Belajar, Hasil Belajar Matematika

\section{Pendahuluan}

Setiap peserta didik mempunyai pandangan yang berbeda tentang pelajaran matematika. Bagi yang menganggap matematika menyenangkan maka akan tumbuh motivasi dalam diri peserta didik untuk mempelajari matematika dan optimis dalam menyelesaikan masalah-masalah yang bersifat menantang dalam pelajaran matematika. Sebaliknya, bagi yang menganggap matematika sebagai pelajaran yang sulit, maka peserta didik tersebut akan bersikap pesimis dalam menyelesaikan masalah matematika dan kurang menyukai pelajaran matematika, 
hal tersebut berdampak pada terhambatnyapencapaian tujuan pembelajaran. Tujuan pembelajaran akan tercapai apabila perencanaan dan metode yang digunakan dapat mempengaruhi potensi dan kemampuan yang dimiliki peserta didik dan keberhasilan tersebut akan tercapai apabila peserta didik dilibatkan dalam proses berpikirnya (Sugilar, 2013:157).

Beberapa faktor yang mempengaruhi keberhasilan peserta didik dalam belajar matematika, diantaranya faktor internal yang meliputi kemampuan awal, tingkat kecerdasan, motivasi belajar, kebiasaan belajar, kecemasan belajar, motivasi belajar, dan sebagainya. Sedangkan faktor eksternal meliputi lingkungan keluarga, lingkungan sekolah, lingkungan masyarakat, keadaan sosial ekonomi, dan sebagainya. Belajar ialah proses perubahan tingkah laku yang disengaja berdasarkan pengalaman yang bukan semata-mata sikap dan nilai tetapi juga penguasaan pengetahuan dan keterampilan. Belajar menurut Hamalik (2001:27), “Belajar adalah modifikasi atau memperteguh kelakuan melalui pengalaman”. Menurut pengertian ini, belajar merupakan proses suatu kegiatan dan bukan hasil atau tujuan. Menurut Sutikno (2004: 67-68), bahwa: "Belajar adalah proses orang memperoleh berbagai kecakapan, keterampilan dan sikap.

Hasil belajar peserta didik dipengaruhi oleh lima faktor yaitu (1) bakat belajar, (2) waktu yang tersedia untuk balajar, (3) kemampuan individu, (4) kualitas pengajaran, (5) lingkungan (Caroll dalam R. Angkowo dan A. Kosasih (2007: 51)). Sedangkan Bloom (1976: 201-207) membagi hasil belajar menjadi kawasan yaitu kognitif, afektif dan psikomotor. Kawasan kognitif berkenaan dengan ingatan atau pengetahuan dan kemampuan intelektual serta keterampilanketerampilan. Kawasan afektif menggambarkan sikap-sikap, minat dan nilai serta pengembangan pengertian atau pengetahuan dan penyesuaian diri yang memadai. Kawasan psikomotor adalah kemampuan-kemampuan menggiatkan dan mengkoordinasikan gerak.

Kemampuan awal peserta didik merupakan faktor penentu dalam keberhasilan pembelajaran matematika. Setiap individu mempunyai kemampuan belajar yang berlainan. Kemampuan awal peserta didik adalah kemampuan yang telah dipunyai oleh peserta didik sebelum ia mengikuti pembelajaran yang akan diberikan. Kemampuan awal (entry behavior) ini menggambarkan kesiapan peserta didik dalam menerima pelajaran yang akan 
disampaikan oleh guru. Ruseffendi (2004:

10) mengatakan bahwa:

" Keberhasilan peserta didik dalam suatu pelajaran atau pendidikan juga tergantung dari kesiapan anak. Kesiapan anak ini ada dua macam, perkembangan mentalnya sudah siap dan pengetahuan prasyaratnya sudah dimiliki. Peserta didik belum bisa mengerti berhitung bila ia belum dapat memahami hukum kekekalan banyaknya (perkembangan mentalnya belum siap) dan ia tidak akan mengerti persamaan kuadrat bila ia belum mengerti persamaan linier (pengetahuan prasyarat belum ada)."

Berdasarkan hasil penelitian menunjukkan bahwa terdapat hubungan positif antara kemampuan awal peserta didik dengan hasil belajarnya. Dengan asumsi bahwa peserta didik yang menjadi subjek penelitian adalah peserta didik yang mempunyai $I Q$ di atas rata-rata, sehingga mereka tidak mengalami kesulitan dalam menerima pelajaran berikutnya. Dengan demikian perhatian guru dapat diarahkan pada kemampuan awal peserta didik, sebelum materi pelajaran disampaikan. Kemampuan awal peserta didik penting untuk diketahui guru sebelum ia mulai dengan pembelajarannya, karena dengan demikian dapat diketahui: a) apakah peserta didik telah mempunyai atau pengetahuan yang merupakan prasyarat (prerequisite) untuk mengikuti pembelajaran; b) sejauh mana peserta didik telah mengetahui materi apa yang akan disajikan. Dengan mengetahui kedua hal tersebut, guru akan dapat merancang pembelajaran dengan lebih baik, sebab apabila peserta didik diberi materi yang telah diketahui maka mereka akan merasa cepat bosan.

\section{Metodologi Penelitian}

Lokasi penelitian ini adalah beberapa SMP Negeri di Kecamatan Pasar Minggu, Jakarta Selatan, dengan asumsi dapat merepresentasikan pengaruh kemampuan awal matematika dan motivasi belajar terhadap hasil belajar matematika peserta didik. Sekolah yang yang dijadikan penelitian adalah SMP Negeri 41, SMP Negeri 218 dan SMP Negeri 227 Jakarta. Teknik sampling yang digunakan dalam penelitian ini adalah dengan menggunakan probability sampling dengan teknik simple random sampling, dimana dari jumlah sampel yang ada diambil secara acak 99 orang peserta didik yang kemudian dijadikan sampel. Penelitian dilakukan selama 3 bulan. Analisis data yang digunakan adalah dengan menggunakan metode survey korelasional. Instrumen penelitian yang digunakan adalah tes matematika dan non tes berupa angket.

Untuk memberikan gambaran yang jelas, maka dapat digambarkan desain penelitian sebagai berikut : 


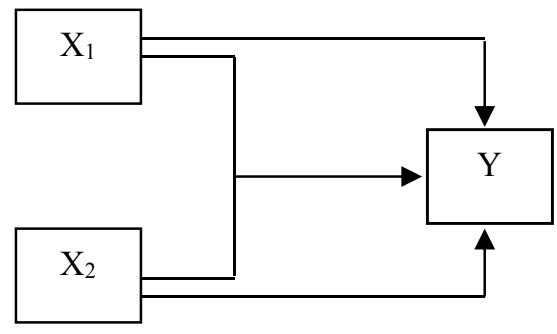

Keterangan: $\mathrm{X} 1=$ Kemampuan Awal

$\mathrm{X} 2=$ Motivasi Belajar

$\mathrm{Y}=$ Hasil Belajar Matematika

\section{Hasil dan Pembahasan}

\section{a. Pengaruh Kemampuan Awal Peserta} Didik terhadap Hasil Belajar

\section{Matematika}

Proses pengujian hipotesis dilakukan dengan menggunakan analisis korelasi ganda, yaitu mencari koefisien pengaruh antar variabel yang satu terhadap variabel lain, baik secara sendiri-sendiri maupun secara bersama-sama. Proses perhitungan ini dilakukan dengan bantuan SPSS 15.0 Dari perhitungan akan didapatkan hasil koefisien korelasi untuk masing-masing variabel. Dalam penelitian ini terdapat tiga hipotesis dan diuji dalam pengujian regresi sederhana, data yang dipakai dalam pengujian ini adalah data hasil belajar matematika peserta didik (Y), kemampuan awal $\left(\mathrm{X}_{1}\right)$ dan motivasi belajar matematika peserta didik $\left(\mathrm{X}_{2}\right)$.

\section{Uji Hipotesis 1}

Ho $=$ tidak terdapat pengaruh yang positif kemampuan awal peserta didik terhadap hasil belajar matematika peserta didik

$\mathrm{H} 1=$ terdapat pengaruh positif kemampuan awal peserta didik terhadap hasil belajar matematika peserta didik

Tabel 1. Hasil Uji Statistik Hipotesis 1

\section{Correlations}

\begin{tabular}{|ll|r|r|}
\hline & & $\begin{array}{c}\text { Kemampuan } \\
\text { Awal }\end{array}$ & $\begin{array}{c}\text { Hasil Belajar } \\
\text { Matematika }\end{array}$ \\
\hline Kemampuan Awal & Pearson Correlation & 1 & $.342^{* *}$ \\
& Sig. (2-tailed) & & .001 \\
& $\mathrm{~N}$ & 99 & 99 \\
\hline Hasil Belajar Matematika & Pearson Correlation & $.342^{* *}$ & 1 \\
& Sig. (2-tailed) & .001 & 99 \\
& $\mathrm{~N}$ & 99 & 9 \\
\hline
\end{tabular}

${ }^{* *}$. Correlation is significant at the 0.01 level (2-tailed). 


\section{Coefficients}

\begin{tabular}{|cl|r|r|c|c|c|}
\hline \multirow{2}{*}{ Model } & \multicolumn{2}{|c|}{$\begin{array}{c}\text { Unstandardized } \\
\text { Coefficients }\end{array}$} & $\begin{array}{c}\text { Standardized } \\
\text { Coefficients }\end{array}$ & & \multirow{2}{*}{} \\
\cline { 2 - 6 } & \multicolumn{2}{|c|}{$\mathrm{B}$} & Std. Error & Beta & \multicolumn{1}{c|}{$\mathrm{t}$} & Sig. \\
\hline 1 & (Constant) & 28.621 & 10.470 & & 2.734 & .007 \\
& Kemampuan Aual & .443 & .123 & .342 & 3.585 & .001 \\
\hline
\end{tabular}

a.Dependent Variable: Hasil Belajar Matematika

Berdasarkan tabel 1 diperoleh angka $\mathrm{R}$ adalah sebesar 0,342 yang berarti bahwa pengaruh kemampuan awal matematika peserta didik terhadap hasil belajar matematika peserta didik adalah sebesar 0,342 yang mengindikasikan bahwa pengaruh tersebut adalah sedang. Dan nilai t hitung seperti pada tabel coefficient, yaitu sebesar 3,585. Nilai t tabel pada taraf $\alpha=$ 0,05:2 (uji 2 sisi) dengan derajat kebebasan (df) = n-k-1 atau 99-2-1 = 96 Dengan pengujian 2 sisi (signifikansi $=0,025$ ) hasil diperoleh untuk t tabel sebesar 2,358.

Dari pengujian hipotesis diperoleh bahwa nilai thitung $>t_{\text {tabel }}(3,585>2,358)$ dan nilai Sig $=$ 0,001 , dengan demikian maka Ho

ditolak dan $\mathrm{H}_{1}$ diterima yang artinya terdapat pengaruh yang positif kemampuan awal matematika peserta didik terhadap hasil belajar matematika peserta didik.

\section{b. Pengaruh Motivasi Belajar terhadap Hasil Belajar Matematika}

Berdasarkan hasil perhitungan dengan menggunakan SPSS 15.0 maka dapat disimpulkan bahwa terdapat pengaruh motivasi belajar terhadap hasil belajar matematika peserta didik. Motivasi dan belajar merupakan dua hal yang saling mempengaruhi. Motivasi belajar dapat timbul karena adanya faktor instrinsik, berupa hasrat keinginan untuk berhasil, dorongan kebutuhan belajar, dan harapan akan cita-cita. Sedangkan faktor ekstrinsiknya adalah adanya penghargaan, lingkungan belajar yang kondusif, dan kegiatan belajar yang menarik. Tetapi harus diingat bahwa kedua faktor tersebut timbul disebabkan oleh rangsangan tertentu, sehingga seseorang berkeinginan untuk melakukan aktivitas belajar yang lebih giat dan semangat.

\section{Uji Hipotesis 2}

Ho $=$ tidak terdapat pengaruh yang positif motivasi belajar matematika peserta didik terhadap hasil belajar matematika peserta didik

$\mathrm{H} 1$ = terdapat pengaruh positif motivasi belajar matematika peserta didik terhadap hasil belajar matematika peserta didik. 
Tabel 2. Hasil Uji Statistik Hipotesis 2

\begin{tabular}{|ll|r|r|}
\multicolumn{1}{c}{ Correlations } & \multicolumn{2}{c|}{$\begin{array}{c}\text { Motivasi } \\
\text { Belajar }\end{array}$} & $\begin{array}{r}\text { Melajar } \\
\text { Matematika }\end{array}$ \\
\hline Motivasi Belajar & Pearson Correlation & 1 & .043 \\
& Sig. (2-tailed) & 99 & .672 \\
Hasil Belajar Matematika & $\mathrm{N}$ & .443 & 99 \\
& Pearson Correlation & .472 & 1 \\
\hline
\end{tabular}

\section{Coefficients}

\begin{tabular}{|c|c|c|c|c|c|c|}
\hline \multirow[b]{2}{*}{ Model } & & \multicolumn{2}{|c|}{$\begin{array}{l}\text { Unstandardized } \\
\text { Coefficients }\end{array}$} & \multirow{2}{*}{$\begin{array}{c}\begin{array}{c}\text { Standardized } \\
\text { Coefficients }\end{array} \\
\text { Beta } \\
\end{array}$} & \multirow[b]{2}{*}{$\mathrm{t}$} & \multirow[b]{2}{*}{ Sig. } \\
\hline & & $B$ & Std. Error & & & \\
\hline 1 & (Constant) & 28.890 & 16.191 & & 3.637 & .000 \\
\hline & Motivasi Belajar & .377 & .181 & .443 & 3.424 & .032 \\
\hline
\end{tabular}

a. Dependent Variable: Hasil Belajar Matematika

Berdasarkan tabel 2 diperoleh angka $\mathrm{R}$ atau korelasinya adalah sebesar 0,443 yang mengindikasikan bahwa pengaruh motivasi belajar terhadap hasil belajar matematika peserta didik adalah lemah. Dari hasil analisis regresi di atas dapat diketahui nilai t hitung seperti pada tabel coefficient, yaitu sebesar 3,424 Nilai t tabel pada taraf $\alpha=$ 0,05:2 (uji 2 sisi) dengan derajat kebebasan $(\mathrm{df})=\mathrm{n}-\mathrm{k}-1$ atau $99-2-1=96$ Dengan pengujian 2 sisi (signifikansi $=0,025$ ) hasil diperoleh untuk $\mathrm{t}$ tabel sebesar 2,358.

Dari pengujian hipotesis diperoleh bahwa nilai $t_{\text {hitung }}>\mathrm{t}_{\text {tabel }}(3,585>2,358)$ dan nilai Sig $=0,032$, dengan demikian maka Ho ditolak dan $\mathrm{H}_{1}$ diterima yang artinya terdapat pengaruh yang positif motivasi belajar terhadap hasil belajar matematika peserta didik. c. Pengaruh Kemampuan Awal

\section{Matematika dan Motivasi Belajar terhadap Hasil Belajar Matematika}

Kemampuan awal merupakan prasyarat yang harus dimiliki peserta didik sebelum memasuki pembelajaran materi pelajaran berikutnya yang lebih tinggi. Jadi seorang peserta didik yang mempunyai kemampuan awal yang baik akan lebih cepat memahami materi dibandingkan dengan peserta didik yang tidak mempunyai kemampuan awal dalam proses pembelajaran. Sedangkan motivasi merupakan keseluruhan daya penggerak baik dari dalam diri maupun dari luar dengan menciptakan serangkaian usaha untuk menyediakan kondisi-kondisi tertentu yang menjamin kelangsungan dan memberikan arah pada kegiatan belajar sehingga tujuan yang dikehendaki oleh 
subjek belajar dapat tercapai. "Seseorang akan berhasil dalam belajar apabila dalam dirinya ada keinginan untuk belajar." (Sardiman A.M.:2001:39)

Potensi peserta didik yang baik dan lengkapnya sarana belajar jika tidak di sertai motivasi, maka proses belajarmengajar tidak akan berjalan dengan optimal. Sehingga bisa di katakan bahwa pencapaian tugas belajar di tentukan oleh proses yang ada di dalamnya, jika proses berjalan optimal (baik dari guru, peserta didik, lingkungan maupun sarana pembelajaran) maka hasilnya akan optimal pula. Semakin tinggi kemampuan awal peserta didik sebelum mengikuti pembelajaran selanjutnya maka akan semakin tinggi pula hasil belajar yang akan diraih. Apalagi jika diikuti motivasi belajar yang tinggi yang dapat memaksimalkan potensi sumber daya yang dimiliki, yang pada akhirnya dapat menghasilkan hasil belajar yang lebih baik.

Dari uraian teoritis tersebut bisa diasumsikan bahwa semakin tinggi kemampuan awal dengan diikuti motivasi belajar yang tinggi maka akan semakin tinggi pula hasil belajar yang didapat, sebaliknya semakin rendah kemampuan awal yang dimiliki peserta didik yang diikuti motivasi belajar yang rendah pula maka hasil belajar yang diperoleh sudah dapat dipastikan akan rendah pula.

\section{Uji Hipotesis 3}

Ho = tidak terdapat pengaruh yang positif kemampuan awal dan motivasi belajar peserta didik terhadap hasil belajar matematika peserta didik

$\mathrm{H} 1$ = terdapat pengaruh positif kemampuan awal dan motivasi belajar peserta didik terhadap hasil belajar matematika peserta didik.

Tabel 3. Hasil Uji Statistik Hipotesis 3

\begin{tabular}{|c|c|c|c|c|}
\hline \multicolumn{5}{|c|}{ Correlations } \\
\hline & & $\begin{array}{c}\text { Kemampuan } \\
\text { Awal }\end{array}$ & $\begin{array}{c}\text { Motivasi } \\
\text { Belajar }\end{array}$ & $\begin{array}{c}\text { Hasil Belajar } \\
\text { Matematika }\end{array}$ \\
\hline \multirow[t]{3}{*}{ Kemampuan Awal } & Pearson Correlation & 1 & .110 & $.342^{\star \star}$ \\
\hline & Sig. (2-tailed) & & .276 & .001 \\
\hline & $\mathrm{N}$ & 99 & 99 & 99 \\
\hline \multirow[t]{3}{*}{ Motivasi Belajar } & Pearson Correlation & .110 & 1 & .043 \\
\hline & Sig. (2-tailed) & .276 & & .672 \\
\hline & $\mathrm{N}$ & 99 & 99 & 99 \\
\hline \multirow[t]{3}{*}{ Hasil Belajar Matematika } & Pearson Correlation & $.342^{\star \star}$ & .043 & 1 \\
\hline & Sig. (2-tailed) & .001 & .672 & \\
\hline & $\mathrm{N}$ & 99 & 99 & 99 \\
\hline
\end{tabular}

${ }^{* *}$. Correlation is significant at the 0.01 level (2-tailed). 


\section{Coefficients}

\begin{tabular}{|c|c|c|c|c|c|c|}
\hline \multirow[b]{2}{*}{ Model } & & \multicolumn{2}{|c|}{$\begin{array}{l}\text { Unstandardized } \\
\text { Coefficients }\end{array}$} & \multirow{2}{*}{$\begin{array}{c}\text { Standardized } \\
\text { Coefficients }\end{array}$} & \multirow[b]{2}{*}{$t$} & \multirow[b]{2}{*}{ Sig. } \\
\hline & & $B$ & Std. Error & & & \\
\hline \multirow[t]{3}{*}{1} & (Constant) & 27.846 & 17.642 & & 1.578 & .118 \\
\hline & Kemampuan Awal & .442 & .125 & .341 & 3.539 & .001 \\
\hline & Motivasi Belajar & .009 & .173 & .005 & .055 & .956 \\
\hline
\end{tabular}

a. Dependent Variable: Hasil Belajar Matematika

Berdasarkan tabel 3 diperoleh angka $\mathrm{R}$ yaitu korelasi ganda antara kemampuan awal dan motivasi belajar peserta didik terhadap hasil belajar matematika peserta didik adalah sebesar 0,342. Dari hasil analisis regresi di atas dapat diketahui nilai t hitung seperti pada tabel coefficient, yaitu sebesar 3,539 dan 0,055. Nilai t tabel pada taraf $\alpha=0,05: 2$ (uji 2 sisi) dengan derajat kebebasan $(\mathrm{df})=\mathrm{n}-\mathrm{k}-1$ atau $99-2-1=96$. Dengan pengujian 2 sisi (signifikansi = $0,025)$ hasil diperoleh untuk $\mathrm{t}$ tabel sebesar 2,358 .

Dari pengujian hipotesis diperoleh bahwa nilai $t_{\text {hitung }}>\mathrm{t}_{\text {tabel }}(3,585>2,358)$ dengan demikian maka Ho ditolak dan $\mathrm{H} 1$ diterima yang artinya terdapat pengaruh yang positif kemampuan awal dan motivasi belajar secara bersama-sama terhadap hasil belajar matematika peserta didik. Berdasarkan hasil perhitungan dengan menggunakan SPSS 15.0 maka dapat disimpulkan bahwa terdapat pengaruh positif dan signifikan kemampuan awal matematika peserta didik terhadap hasil belajar matematika peserta didik.

Berdasarkan hasil penelitian dan uji statistik dapat disimpulkan bahwa motivasi mempengaruhi hasil belajar siswa. Untuk itu motivasi belajar siswa harus ditingkatkan melalui peran serta guru membangkitkan motivasi belajar siswa misalnya memberikan reward kepada siswa yang nilainya bagus atau memberikan spirit dan semangat akan pentingnya belajar dengan tayangan video motivasi. Kemampuan awal siswa juga mempengaruhi hasil belajar, hal ini dikarenakan siswa yang kemampuan awal atau memahami materi prasyarat dengan baik sedikit kemungkinan mengalami kesulitan dalam mempelajari materi dibandingkan dengan siswa yang kemampuan awalnya rendah.

\section{Simpulan dan Saran}

Hasil penelitian membuktikan bahwa kemampuan awal mempunyai pengaruh kuat terhadap hasil belajar, oleh karena itu 
untuk mengembangkan kemampuan awal peserta didik harus lebih meningkatkan porsi latihan untuk belajar matematika dan banyak membaca di luar sekolah sebagai bekal pengetahuan awal. Terdapat pengaruh kemampuan awal terhadap hasil belajar matematika peserta didik. Terdapat pengaruh motivasi belajar terhadap hasil belajar matematika peserta didik.Terdapat pengaruh interaksi antara kemampuan awal dan motivasi belajar terhadap hasil belajar matematika. Guru sebagai unsur terdepan dalam pembelajaran harus memperhatikan strategi apa yang harus dilakukan agar peserta didik mampu belajar dengan baik pada mata pelajaran matematika. Dengan memberikan pembelajaran yang baik dan sesuai dengan keinginan peserta didik maka dapat membangkitkan motivasi belajar peserta didik yang pada akhirnya berpengaruh pada hasil belajarnya.

\section{Daftar Pustaka}

Angkowo, R., dan Kosasih, A. 2007. Optimalisasi Media Pembelajaran. Jakarta: PT.Grasindo

M. Ngalim purwanto.1992. Psikologi Pendidikan. Jakarta: PT. Remaja Rosdakarya.

Oemar. H.2001. Proses Belajar Mengajar. Jakarta: Bumi Aksara.

Hamzah B. Uno. 2007. Teori Motivasi dan Pengukurannya Analisis di Bidang Pendidikan. Jakarta: Bumi Aksara

Russefendi, E.T. 2004. Pengajaran Matematika Modern. Bandung: Tarsito

Sardiman. 2001. Interaksi dan Motivasi Belajar Mengajar. Jakarta: Raja Grafindo

Sugilar, H. 2013. Meningkatkan Kemampuan Berpikir Kreatif dan Disposisi Matematik Siswa Madrasah Tsanawiyah Melalui Pembelajaran Generatif. [online] Jurnal Ilmiah Program Studi Matematika STKIP Siliwangi Bandung, Vol 2, No 2, September 2013.

Sutikno M. Sobry. (2004). Menuju Pendidikan Bermutu. Mataram: NTP Press. 